\title{
Detection of fusion transcripts in the serum samples of patients with hepatocellular carcinoma
}

\author{
Yan-Ping Yu' ${ }^{1}$, Allan Tsung ${ }^{1,2}$, Silvia Liu', Michael Nalesnick${ }^{1}$, David Geller ${ }^{1}$, \\ George Michalopoulos' and Jian-Hua Luo' \\ ${ }^{1}$ Department of Pathology and Surgery, University of Pittsburgh School of Medicine, Pittsburgh, PA 15261, USA \\ ${ }^{2}$ Current address: Department of Surgery, Ohio State University School of Medicine, Columbus, Ohio 43210, USA \\ Correspondence to: Jian-Hua Luo, email: luoj@upmc.edu \\ Keywords: serum detection; fusion transcript; cell-free RNA; HCC \\ Received: February 25, $2019 \quad$ Accepted: April 04, $2019 \quad$ Published: May 21, 2019 \\ Copyright: Yu et al. This is an open-access article distributed under the terms of the Creative Commons Attribution License 3.0 \\ (CC BY 3.0), which permits unrestricted use, distribution, and reproduction in any medium, provided the original author and source \\ are credited.
}

\section{ABSTRACT}

Hepatocellular carcinoma is one of the most lethal cancers in the United States. Early detection of the disease is crucial for reducing the mortality of this malignancy. Recently, we identified a panel of fusion genes present in several types of human cancers, including hepatocellular carcinoma. Among 8 fusion genes, MAN2A1-FER, TRMT11-GRIK2 and CCNH-C5orf30 appear most frequently in hepatocellular carcinoma samples. In this study, we showed that the fusion transcripts of MAN2A1-FER, CCNHC5orf30 and SLC45A2-AMACR were detected in the serum samples of liver cancer patients as circulating cell-free RNA. The distributions of these gene fusion RNA fragments largely matched those of the primary HCC samples. In contrast, the sera of all healthy individuals free of human malignancies were shown to be negative for these fusion genes. These results suggest that gene fusion RNA is frequently shed from liver cancer cells. The detection of serum cell-free fusion transcripts may provide a new approach to aid in the diagnosis, follow-up or therapy of liver cancers.

\section{INTRODUCTION}

Human cancer is one of the most frequent causes of death in the United States. In 2018, the mortality rate of cancer reached 606,880 in the US [1], making cancer the second most lethal cause of death after cardiovascular diseases [2]. Hepatocellular carcinoma (HCC) is one of the most lethal malignancies, accounting for more than 31,000 deaths in the US alone [1]. The five-year survival rate for $\mathrm{HCC}$ is approximately $18 \%$. Only pancreatic adenocarcinoma and glioblastoma multiforme have lower survival rates [3]. The development of early detection methods and effective treatment for HCC is urgently needed to reduce the mortality of this disease.

Treating liver cancer in the early clinical stages offers a significant advantage for therapeutic options and a better prognosis [4]. Currently, surgical resection, ablation and liver transplant are the most effective approaches to treating early- stage HCC [5, 6]. HCC patients treated with these approaches typically survive long-term and can even be considered cured of the disease. However, patients with late clinical stage HCC without similar options of surgical intervention usually survive less than a year. Thus, early detection of HCC is crucial for reducing the mortality of liver cancer. Recently, we identified a panel of 8 fusion genes in human cancers [7-9]. Some of these fusion genes were shown to be present in a large proportion of HCC cancer samples [7, 10]. The mechanisms underlying these gene fusions are chromosomal translocation and rearrangement [8-10]. The presence of these fusion transcripts in liver cancer samples indicates that translocation and chromosomal rearrangement are common in liver cancer cells. To investigate the utility of these fusion transcripts in detecting liver cancer, we performed TaqMan qRT-PCR on the RNA extracted from cell-free serum. The results suggest that many of these fusion genes are detectable as cell-free circulating RNA. 


\section{RESULTS}

One of the hallmarks of genomes of human cancer is chromosomal rearrangement and translocation [11, 12]. Previously, we identified a panel of fusion genes in prostate cancer samples from patients who experienced poor clinical outcomes. Subsequent analyses showed that many of these fusion genes are present in a variety of human cancers, including liver cancer $[7,10]$. To investigate whether these fusion transcripts are detectable in the sera of HCC patients, we analyzed the presence or absence of 8 fusion genes in 118 serum samples from HCC patients and individuals free of malignant tumors. As shown in Table 1, all serum samples from individuals free of malignancies were negative (0/14) for the fusion transcripts of all the fusion genes. In contrast, $83.7 \%$ (87/104) of the serum samples from HCC patients were positive for at least one fusion transcript. Interestingly, all serum samples obtained from HCC patients with nonalcoholic steatohepatitis etiology $(n=20)$ were positive for at least one fusion gene ( $\mathrm{p}=0.019)$ : $100 \%(20 / 20)$ versus $77.6 \%(59 / 76)$. The fusion gene is also more likely present in the serum samples from HCC patients with steatohepatitis background $(\mathrm{p}=0.02): 100 \%(20 / 20)$ versus $78.5 \%$ (62/79). Interestingly, multiple fusion transcripts (at least 2) detected in the serum are associated with moderate differentiation of HCC $(42.4 \%$ [14/33] versus $9.5 \%$ [2/21] for all other category, $\mathrm{p}=0.014$ ).

Upon analyzing individual fusion transcripts, we determined that MAN2A1-FER was frequently detected in the sera of HCC patients, reaching $78.8 \%(82 / 104$, Table 2). SLC45A2-AMAMCR occurred at a frequency of $31.7 \%(33 / 104)$, while CCNH-C5orf30 occurred at a frequency of $10.6 \%(11 / 104)$. All HCC patients with NASH were positive for MAN2A1-FER in their serum samples $(20 / 20)$, indicating a strong association between MAN2A1-FER and the etiology of NASH ( $\mathrm{p}=0.005)$.

To determine whether the HCC samples from the same patients were positive for these fusion genes, six liver cancer samples from these HCC patients were analyzed. As shown in Table 3 and Figure 1, MAN2A1-FER and CCNH-C5orf30 were positive in all six HCC samples,

\section{Case\#}

2274
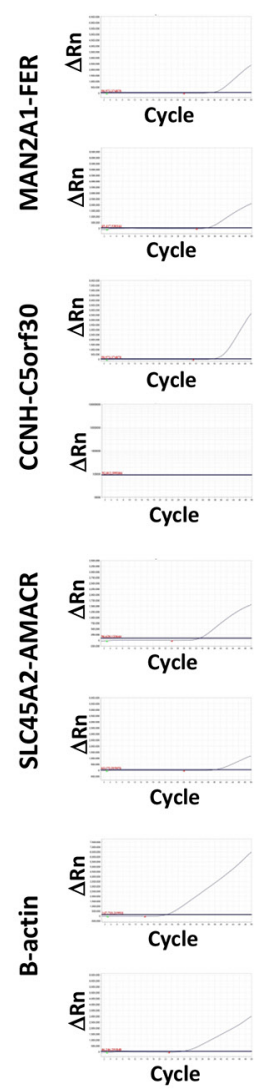

2298

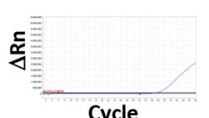

Cycle

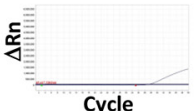

零
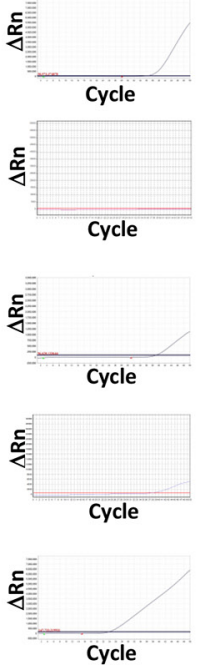

宅

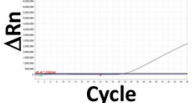

2209

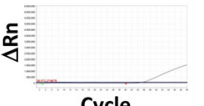

Cycle
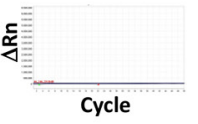

实

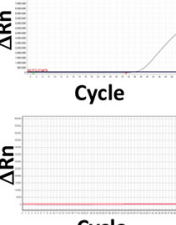

Cycle

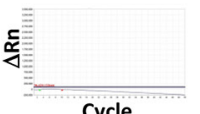

Cycle

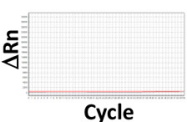

Cycle
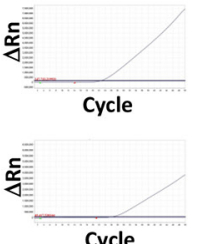

2128
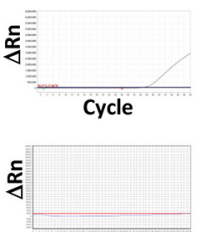

Cycle
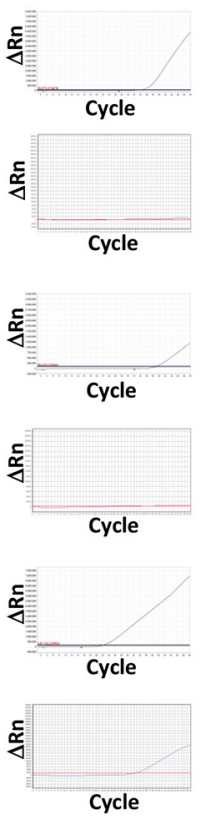

2218
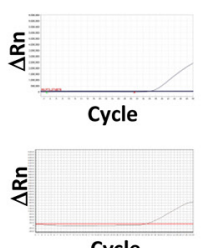

Cycle
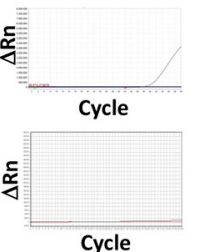

Cycle
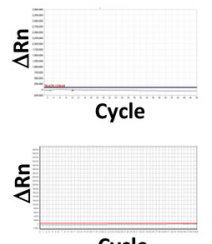

Cycle

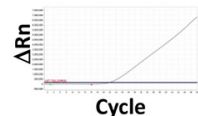

Cycle

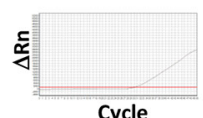

2172

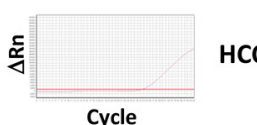

Cycle
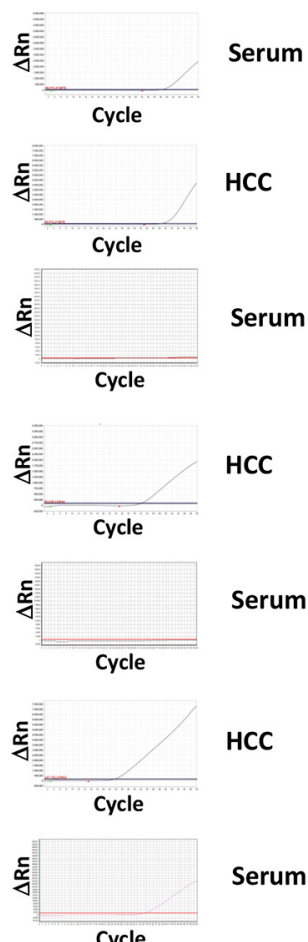

Figure 1: Detection of MAN2A1-FER, CCNH-C5orf30 and SLC45A2-AMACR in HCC samples and the corresponding serum samples. Six cases of HCC and matched serum samples were analyzed for the presence of transcripts of MAN2A1-FER, CCNHC5orf30 and SLC45A2-AMACR using TaqMan qRT-PCR. The results of $\beta$-actin were used as normalization controls. Assays were performed twice independently. Sanger sequencing was performed on $20 \%$ of all positive samples. 
Table 1: Fusion transcripts detection in the sera of HCC patients

\begin{tabular}{|c|c|c|}
\hline Clinical characteristics & Fusion gene positive & Fusion gene negative \\
\hline \multicolumn{3}{|l|}{ HCC patients } \\
\hline \multicolumn{3}{|l|}{ Age: } \\
\hline $40 \mathrm{~s}$ & 5 & 0 \\
\hline $50 \mathrm{~s}$ & 22 & 2 \\
\hline $60 \mathrm{~s}$ & 33 & 11 \\
\hline $70 \mathrm{~s}$ & 20 & 1 \\
\hline $80 \mathrm{~s}$ & 4 & 3 \\
\hline \multicolumn{3}{|l|}{ Etiology: } \\
\hline $\mathrm{HCV}$ & 44 & 8 \\
\hline $\mathrm{HBV}$ & 6 & 2 \\
\hline Ethanol & 34 & 9 \\
\hline NASH & 20 & 0 \\
\hline Other & 4 & 4 \\
\hline \multicolumn{3}{|l|}{ Background liver: } \\
\hline Cirrhosis/fibrosis & 81 & 17 \\
\hline Steatosis & 12 & 4 \\
\hline Steatohepatitis & 20 & 0 \\
\hline \multicolumn{3}{|l|}{ Recurrent status: } \\
\hline Recurrent & 20 & 2 \\
\hline Non-recurrent & 50 & 11 \\
\hline \multicolumn{3}{|l|}{ Response to therapy: } \\
\hline Responsive & 31 & 8 \\
\hline Progressive & 42 & 6 \\
\hline \multicolumn{3}{|l|}{ Pathology grade: } \\
\hline Poorly differentiated & 5 & 0 \\
\hline Moderately differentiated & 28 & 5 \\
\hline Well differentiated & 18 & 6 \\
\hline Death & 40 & 7 \\
\hline Alive & 42 & 9 \\
\hline Healthy individuals & 0 & 14 \\
\hline
\end{tabular}

while 4 of 6 HCC samples were positive for SLC45A2AMACR. All positive serum samples corresponded to the matched positive $\mathrm{HCC}$ samples, indicating that the source of the seral fusion transcripts was the liver cancer. Two serum samples were negative for MAN2A1-FER, while the matched $\mathrm{HCC}$ samples were positive for the fusion gene. Similarly, two HCC samples positive for SLC45A2AMACR had matched serum samples that were negative for the same fusion gene. Even though TRMT11-GRIK2 and CCNH-C5orf30 were present in all six HCC samples, the transcripts of these fusion genes were undetectable in the sera of the same patients. Half of the HCC samples were also positive for LRRC59-FLJ60017, but the fusion transcript was not detected in the matched serum samples. Based on these results, MAN2A1-FER appears to be the most sensitive marker for serum detection of $\mathrm{HCC}$ (4/6 or $67 \%$ ). SLC45A2-AMACR ranks second (2/4 or $50 \%$ ), while TRMT11-GRIK2 and CCNH-C5orf30 are the most insensitive markers $(0 / 6$ or $0 \%)$. These results suggest that these fusion transcripts have different levels 
Table 2: Frequency of individual fusion transcript detected in the sera of HCC patients

\begin{tabular}{|c|c|c|c|c|c|c|c|c|}
\hline Clinical features & $\begin{array}{c}\text { MAN2A1- } \\
\text { FER }\end{array}$ & $\begin{array}{c}\text { TRMT11- } \\
\text { GRIK2 } \\
\end{array}$ & $\begin{array}{c}\text { MTOR- } \\
\text { TP53BP1 }\end{array}$ & $\begin{array}{l}\text { CCNH- } \\
\text { C5orf30 } \\
\end{array}$ & $\begin{array}{c}\text { KDM4B- } \\
A C 011523.2\end{array}$ & $\begin{array}{c}\text { SLC45A2- } \\
\text { AMACR }\end{array}$ & $\begin{array}{c}\text { TMEM135- } \\
\text { CСDC67 }\end{array}$ & $\begin{array}{l}\text { LRRC59- } \\
\text { FLJ60017 }\end{array}$ \\
\hline All HCC patients & $83 / 104$ & $0 / 104$ & $0 / 104$ & $11 / 104$ & $0 / 104$ & $33 / 104$ & $0 / 104$ & $0 / 104$ \\
\hline \multicolumn{9}{|l|}{ Ages: } \\
\hline$>80 \mathrm{~s}$ & $11 / 15$ & $0 / 15$ & $0 / 15$ & $0 / 15$ & $0 / 15$ & $6 / 15$ & $0 / 15$ & $0 / 15$ \\
\hline $70 \mathrm{~s}$ & $21 / 22$ & $0 / 22$ & $0 / 22$ & $2 / 22$ & $0 / 22$ & $7 / 22$ & $0 / 22$ & $0 / 22$ \\
\hline $60 \mathrm{~s}$ & $36 / 48$ & $0 / 48$ & $0 / 48$ & $8 / 48$ & $0 / 48$ & $11 / 48$ & $0 / 48$ & $0 / 48$ \\
\hline $50 \mathrm{~s}$ & $12 / 14$ & $0 / 14$ & $0 / 14$ & $1 / 14$ & $0 / 14$ & $5 / 14$ & $0 / 14$ & $0 / 14$ \\
\hline $40 \mathrm{~s}$ & $2 / 2$ & $0 / 2$ & $0 / 2$ & $0 / 2$ & $0 / 2$ & $2 / 2$ & $0 / 2$ & $0 / 2$ \\
\hline \multicolumn{9}{|l|}{ Etiology: } \\
\hline $\mathrm{HCV}$ & $42 / 54$ & $0 / 54$ & $0 / 54$ & $8 / 34$ & $0 / 54$ & $19 / 54$ & $0 / 54$ & $0 / 54$ \\
\hline $\mathrm{HBV}$ & $7 / 8$ & $0 / 8$ & $0 / 8$ & $1 / 8$ & $0 / 8$ & $1 / 8$ & $0 / 8$ & $0 / 8$ \\
\hline Ethanol & $31 / 43$ & $0 / 43$ & $0 / 43$ & $2 / 43$ & $0 / 43$ & $11 / 43$ & $0 / 43$ & $0 / 43$ \\
\hline NASH & $21 / 21$ & $0 / 21$ & $0 / 21$ & $4 / 21$ & $0 / 21$ & $7 / 21$ & $0 / 21$ & $0 / 21$ \\
\hline Other & $2 / 5$ & $0 / 5$ & $0 / 5$ & $0 / 5$ & $0 / 5$ & $0 / 5$ & $0 / 5$ & $0 / 5$ \\
\hline \multicolumn{9}{|l|}{ Background liver: } \\
\hline Cirrhosis/fibrosis & $81 / 101$ & $0 / 101$ & $0 / 101$ & $12 / 101$ & $0 / 101$ & $28 / 101$ & $0 / 101$ & $0 / 101$ \\
\hline Steatosis & $11 / 16$ & $0 / 16$ & $0 / 16$ & $0 / 16$ & $0 / 16$ & $7 / 16$ & $0 / 16$ & $0 / 16$ \\
\hline Steatohepatitis & $20 / 21$ & $0 / 21$ & $0 / 21$ & $3 / 21$ & $0 / 21$ & $7 / 21$ & $0 / 21$ & $0 / 21$ \\
\hline \multicolumn{9}{|l|}{ Recurrent status: } \\
\hline Recurrent & $20 / 22$ & $0 / 22$ & $0 / 22$ & $2 / 22$ & $0 / 22$ & $5 / 22$ & $0 / 22$ & $0 / 22$ \\
\hline Non-recurrent & $50 / 63$ & $0 / 63$ & $0 / 63$ & $10 / 63$ & $0 / 63$ & $20 / 63$ & $0 / 63$ & $0 / 63$ \\
\hline \multicolumn{9}{|c|}{ Response to therapy: } \\
\hline Responsive & $29 / 38$ & $0 / 38$ & $0 / 38$ & $5 / 38$ & $0 / 38$ & $12 / 38$ & $0 / 38$ & $0 / 38$ \\
\hline Progressive & $42 / 49$ & $0 / 49$ & $0 / 49$ & $7 / 49$ & $0 / 49$ & $16 / 49$ & $0 / 49$ & $0 / 49$ \\
\hline \multicolumn{9}{|c|}{ Pathology differentiation grade: } \\
\hline Poor & $4 / 5$ & $0 / 5$ & $0 / 5$ & $0 / 5$ & $0 / 5$ & $3 / 5$ & $0 / 5$ & $0 / 5$ \\
\hline Moderate & $26 / 34$ & $0 / 34$ & $0 / 34$ & $5 / 34$ & $0 / 34$ & $5 / 34$ & $0 / 34$ & $0 / 34$ \\
\hline Well & $18 / 24$ & $0 / 24$ & $0 / 24$ & $2 / 24$ & $0 / 24$ & $3 / 24$ & $0 / 24$ & $0 / 24$ \\
\hline Death & $39 / 48$ & $0 / 48$ & $0 / 48$ & $5 / 48$ & $0 / 48$ & $17 / 48$ & $0 / 48$ & $0 / 48$ \\
\hline Alive & $41 / 51$ & $0 / 51$ & $0 / 51$ & $5 / 51$ & $0 / 51$ & $15 / 51$ & $0 / 51$ & $0 / 51$ \\
\hline Healthy person & $0 / 14$ & $0 / 14$ & $0 / 14$ & $0 / 14$ & $0 / 14$ & $0 / 14$ & $0 / 14$ & $0 / 14$ \\
\hline
\end{tabular}

of detectability in the blood, probably due to differences in the sensitivity of these RNA sequences to circulating RNAses.

\section{DISCUSSION}

Cancer-specific gene fusions are the result of chromosomal rearrangement and translocation [8].
Many gene fusion events are not specific to one type of cancer. Indeed, most of the fusion genes we discovered in prostate cancer were later detected in a variety of human malignancies, including HCC [7, 10]. MAN2A1-FER and SLC45A2-AMACR belong to a class of fusion genes with gain of function. The MAN2A1-FER gene fusion generates a new chimera protein in which the $\mathrm{C}$-terminal glycoside hydrolase of mannosidase alpha, class 2A, 
Table 3: Fusion gene detection in serum versus matched $\mathrm{HCC}$ tissue

\begin{tabular}{|c|c|c|c|c|c|c|c|c|}
\hline Case No. & $\begin{array}{c}M A N 2 A 1- \\
F E R\end{array}$ & $\begin{array}{c}\text { TRMT11- } \\
\text { GRIK2 }\end{array}$ & $\begin{array}{c}\text { MTOR- } \\
\text { TP53BP1 }\end{array}$ & $\begin{array}{l}\text { CCNH- } \\
\text { C5orf30 }\end{array}$ & $\begin{array}{c}\text { KDM4B- } \\
A C 011523.2\end{array}$ & $\begin{array}{c}S L C 45 A 2- \\
A M A C R\end{array}$ & $\begin{array}{c}\text { TMEM135- } \\
\text { CСDC67 }\end{array}$ & $\begin{array}{l}\text { LRRC59- } \\
\text { FLJ60017 }\end{array}$ \\
\hline \multicolumn{9}{|l|}{2274} \\
\hline HCC tissue & + & + & - & + & - & + & - & - \\
\hline Serum & + & - & - & - & - & + & - & - \\
\hline \multicolumn{9}{|l|}{2298} \\
\hline HCC tissue & + & + & - & + & - & + & - & - \\
\hline Serum & + & - & - & - & - & + & - & - \\
\hline \multicolumn{9}{|l|}{2209} \\
\hline HCC tissue & + & + & - & + & - & - & - & + \\
\hline Serum & - & - & - & - & - & - & - & - \\
\hline \multicolumn{9}{|l|}{2128} \\
\hline $\mathrm{HCC}$ tissue & + & + & + & + & - & + & - & + \\
\hline Serum & - & - & - & - & - & - & - & - \\
\hline \multicolumn{9}{|l|}{2218} \\
\hline HCC tissue & + & + & - & + & - & - & - & - \\
\hline Serum & + & - & - & - & - & - & - & - \\
\hline \multicolumn{9}{|l|}{2172} \\
\hline HCC tissue & + & + & - & + & + & + & - & + \\
\hline Serum & + & - & - & - & - & - & - & - \\
\hline
\end{tabular}

member 1 (MAN2A1) is replaced with an intact tyrosine kinase domain from FER $[9,10]$. The new chimera protein exhibits an almost 4-fold increase in tyrosine kinase activity compared with that of the native FER, and the chimera protein is translocated to the Golgi apparatus [10]. The resulting chimera protein transforms immortalized cells into cancer through the ectopic phosphorylation of growth factor receptor [10]. MAN2A1-FER was detected in $15 \%$ of human HCC samples, and this fusion protein was shown to be a driver of mouse liver cancer [10]. SLC45A2-AMACR was also detected in a lung cancer cell line [13] and urothelial carcinoma [14], in addition to prostate cancer $[9,15]$. To our knowledge, this is the first report showing that SLC45A2-AMACR is present in $\mathrm{HCC}$ and the corresponding serum samples. AMACR is a racemase responsible for branch fatty acid metabolism, while SLC45A2 is a solute transporter. The fusion generates a chimera protein such that 5 transmembrane domains of SLC45A2 are removed from its C-terminus and replaced with an intact racemase domain from AMACR. The overexpression of AMACR was shown to be associated with the aggressive behavior of multiple human cancers [16-25]. In vitro, AMACR was shown to increase cell growth and proliferation [26].

CCNH-C5orf30 and TRMT11-GRIK2 belong to a class of fusion genes with loss of function. CCNH-
C5orf30 was detected in 37\% of HCC samples [10], while TRMT11-GRIK2 was detected in $12.9 \%$ of HCC samples [7]. The gene fusion of CCNH-C5orf30 produces a truncation of the $\mathrm{H}^{\prime}$ and $\mathrm{HC}$ domains of cyclin $\mathrm{H}$ $(\mathrm{CCNH})$, which is an important cell cycle regulator for the progression to mitosis $[27,28]$, and an independent C5orf30 protein. The truncated $\mathrm{CCNH}$ in the fusion gene is defective in binding with cdk7 [29] and may be defective in its transcriptional activity and promotion of the cell cycle. A more dramatic loss of function is identified in the TRMT11-GRIK2 gene fusion; the TRMT11-GRIK2 gene fusion eliminates the open-reading frame of GRIK2, which is a potential tumor suppressor $[30,31]$, and produces a large truncation of TRMT11, which is a tRNA methyltransferase $[32,33]$. Thus, the fusion event is equivalent to the structural deletion of both TRMT11 and GRIK2 genes. The deletion of TRMT11 reduces the stability of tRNA and may therefore adversely impact the protein translation of cancer cells, while the loss of GRIK2 may promote the growth of cancer cells. All these gene fusion events may play important roles in the development of human liver cancer.

The abnormal chromosomal recombination that generates these fusion genes is cancer-specific and is absent in normal tissues [8]. The frequent presence of these fusion transcripts in the serum samples of HCC 
patients suggests that these RNAs are derived from liver cancer cells. Three lines of evidence support the hypothesis that the fusion RNA fragments detected in the serum are shed from liver cancer cells. First, the pattern of fusion transcript distribution in the serum completely overlaps that of the corresponding liver cancer samples, i.e., there is no fusion transcript that is positive in the serum but negative in the matched liver cancer sample. Second, all serum samples from healthy individuals are negative for these fusion transcripts. Normal individuals do not produce these fusion genes. Third, the normalized quantities of the detected fusion transcripts in the serum are generally 4- to 16-fold lower than those detected in the corresponding HCC samples, suggesting the shedding of RNAs from a fraction of cancer cells.

Early detection of $\mathrm{HCC}$ is probably the most effective way to reduce the mortality of the disease, due to the availability of many effective surgical treatments. Unfortunately, at the time of diagnosis, the HCCs of many patients are at the advanced stages, eliminating many options for curing the disease [4]. Currently, the primary means of diagnosing $\mathrm{HCC}$ relies on radiology imaging of liver cancers. The screening of HCC for patients with cirrhosis and chronic liver diseases involves biannual ultrasonography [4]. This screening method may be combined with a seral test for $\alpha$-fetoprotein or other imaging analyses, such as MRI, CT and contrast-enhanced ultrasound, if a suspicious nodule appears. The presence of fusion transcripts from HCC cancer cells in the serum may represent a new approach for detecting liver cancer. Since the test is minimally invasive, it can be employed regularly in conjunction with ultrasound screening for patients with chronic liver disease or cirrhosis. When a suspicious nodule is detected, the presence of a fusion transcript may help to confirm the diagnosis. All 14 healthy individuals negative for the fusion transcript had no known liver disease and were cancer-free. The high frequency of fusion genes in liver cancer implies that gene fusion in the cancer genome is an early event for liver cancer development. It is of interest to investigate whether these fusion genes are also present in some of the HCC precursor lesions such as NASH. So far, the fusion transcripts appear cancer-specific. The serum detection of these fusion genes may provide a sensitive follow-up test for patients undergoing surgical resection or liver transplant to monitor the recurrence of liver cancer. A new therapeutic approach was recently developed to target the chromosomal breakpoints of these fusion genes using the CRISPR-cas9 gene editing system [34]. This approach led to the partial remission of xenografted human liver cancers when the animals were treated with reagents targeting the breakpoint of the MAN2A1-FER fusion gene [34]. As a result, the detection of these fusion genes in HCC may have significant therapeutic implications. The utilization of cell-free fusion RNA in the circulation as tumor markers may provide an important means for early detection, follow-up and therapeutic guidance for the management of HCC patients.

\section{MATERIALS AND METHODS}

\section{Tissue samples}

The 124 tissue specimens and serum samples used in this study consisted of 6 hepatocellular carcinoma samples from HCC patients, 104 serum samples from HCC patients and 14 serum samples from noncancerous patients. These samples were obtained from the University of Pittsburgh Tissue Bank in compliance with institutional regulatory guidelines. The informed consent exemptions and protocol were approved by the Institution Review Board of the University of Pittsburgh. All serum samples and hepatocellular carcinoma samples were fresh-frozen and stored at $-80^{\circ} \mathrm{C}$. Some cases have multiple etiologies, pathological features, and backgrounds. They were classified multiple times. When statistical analyses were performed, however, the duplication was excluded from the analyses. HCC cases that do not contain the specific clinical information were also excluded from the analyses.

\section{RNA extraction, cDNA synthesis and detection of fusion genes}

The procedures for RNA extraction, cDNA synthesis and the detection of fusion genes were described previously [35-49]. Briefly, total RNA was extracted using Trizol to lyse the cells in the cancer tissues (Invitrogen, CA, USA). First strand cDNA was synthesized using $\sim 2 \mu \mathrm{g}$ of RNA from each sample, random hexamers and Superscript II ${ }^{\mathrm{TM}}$ (Invitrogen, Inc, CA, USA) at $42^{\circ} \mathrm{C}$ for 2 hours. One microliter of each cDNA sample was used for the TaqMan PCR reactions with 50 heat cycles, as follows: $94^{\circ} \mathrm{C}$ for 30 seconds, $61^{\circ} \mathrm{C}$ for 30 seconds, and $72^{\circ} \mathrm{C}$ for 30 seconds. The following primers and probes were used: MAN2A1-FER (AGCGCAGTTTGGGATACAGCA/ CTTTAATGTGCCCTTATATACTTCACC; TaqMan probe, 5'/56-FAM/TCAGAAAC A/ZEN/GCCTATGAGG GAAATT/3IABkFQ/3'), SLC45A2-AMACR (TTGAT GTCTGCTCCCATCAGG/CAGCTGGAGTTTCTCCAT GAC; TaqMan probe, 5'-/56-FAM/AAGAGGGCA/ZEN/ TGGTAGTGGAGGC/3IABkFQ/-3'), CCNH-C5orf30 (AAAGTTATTTATCAGAGAGTCTGATGCTG/CTGTT CTACTCCAGGTATTTTCATTATATC; TaqMan probe, 5'-/56-FAM/ACAGGCAAG/ZEN/TTCTGTTCTCTTTC AGCA/3IABkFQ/-3'), mTOR-TP53BP1 (TGATAGA CCAGTCCCGGGATG / CCACTGACATTCCCAGA ACAAG; TaqMan probe, 5'-/56-FAM/ TGTCAGCCT/ ZEN/GTCAGAATCCAAGTCAAG/3IABkFQ/-3'), TRM T11-GRIK2 (GCGCTGTCGTGTACCCTTAAC / GAAT GCAAGTTCCTCAGCTCC; TaqMan probe, 5'-/56-FAM/ CGGAACTCC/ZEN/AGATGCTCCTGCG/3IABkFQ/ 
-3'), LRRC59-FLJ60017 (GTGACTGCTTGGATG AGAAGC / CCCTCCTCTGGTTTGTTGTTG; TaqMan probe, 5'-/56-FAM/CAGTGTGCA/ZEN/AACAAGGT GACTGGAAG/3IABkFQ/-3'), TMEM135-CCDC67 (CAGCTGTCATGGAAGTTCAGAC / CCTCATTCT TTCCTGCTCAGAG; TaqMan probe, 5'-/56-FAM/ AGTTCCTTT/ZEN/TAAGACTCACCAAGGGCAA/3IA $\mathrm{BkFQ} / 3^{\prime}$ ), KDM4- AC011523.2 (AGACC ACCTTCGCCTGGCAC / TCTCTCTCAGATCCAG GCTTG; TaqMan probe, 5'-/56-FAM/ACAGCATCA/ZEN/ ACTACCTGCACTTTGGG/3IABkFQ/-3'), and $\beta$-actin (ACCCCACTTCTCTCTAAGGAG / GCAATGCTATC ACCTCCCCTG; TaqMan probe, 5'-/56-FAM/CCA GTCCTC/ZEN/TCCCAAGTCCACAC/3IABkFQ/-3').

The PCR reactions were performed in a thermocycler (Eppendorf Realplex ${ }^{\mathrm{TM}}$ thermocycler). A negative control and synthetic positive control were included in each batch of reactions. The PCR products were gel-purified and Sanger-sequenced for $20 \%$ of the positive samples.

\section{Abbreviations}

AC011523.2, Homo sapiens chromosome 19 clone LLNLF-214C7; AMACR, Alpha-methylacylCoA racemase; C5orf30, Chromosome 5 openreading frame 30; CCNH, Cyclin H; FER, Fez related tyrosine kinase; FLJ60017, Homo sapiens cDNA FLJ60017; GRIK2, Glutamate ionotropic receptor kainate type subunit 2; HCC, Hepatocellular carcinoma; KDM4B, Lysine demethylase 4B; LRRC59, Leucine rich repeat containing 59; MAN2A1, Mannosidase class 2 member A1; mTOR, Mechanistic target of rapamycin kinase; qRT-PCR, quantitative reversed transcription polymerase chain reaction; SLC45A2, Solute carrier family 45 member 2; TP53BP1, Tumor protein p53 binding protein 1; TRMT11, tRNA methyltransferase 11 homolog

\section{Author contributions}

YY designed and supervised the experiment. SL performed the statistical analyses. AT, DG and MN provided the samples. MG provided experimental and clinical advices. JHL conceived the idea and oversaw the project.

\section{ACKNOWLEDGMENTS AND FUNDING}

We thank Songyang Zheng for the technical support. This work wa s partly supported by grants from the National Cancer Institute (RO1 CA098249 and 1R56CA229262-01 to JHL) and the Department of Defense (W81XWH-16-1-0541 to JHL).

\section{Ethics statement}

All the patients provided written informed consent and patient anonymity has been preserved. Investigation was conducted according to the principles expressed in the Declaration of Helsinki. The study was approved by the institutional review board of University of Pittsburgh.

\section{CONFLICTS OF INTEREST}

All authors declare no conflicts of interest related to the study.

\section{REFERENCES}

1. Siegel RL, Miller KD, Jemal A. Cancer statistics, 2019. CA Cancer J Clin. 2019; 69:7-34. https://doi.org/10.3322/caac.21551. [PubMed]

2. Siegel RL, Miller KD, Jemal A. Cancer statistics, 2018. CA Cancer J Clin. 2018; 68:7-30. https://doi.org/10.3322/caac.21442. [PubMed]

3. Llovet JM, Zucman-Rossi J, Pikarsky E, Sangro B, Schwartz M, Sherman M, Gores G. Hepatocellular carcinoma. Nat Rev Dis Primers. 2016; 2:16018. https://doi.org/10.1038/nrdp.2016.18. [PubMed]

4. Plentz RR, Malek NP. Early Detection of Hepatocellular Carcinoma: How to Screen and Follow up Patients with Liver Cirrhosis According to the GERMAN S3 Guideline? Diagnostics (Basel). 2015; 5:497-503. https://doi.org/10.3390/diagnostics5040497. [PubMed]

5. She WH, Chan AC, Cheung TT, Lo CM, Chok KS. Survival outcomes of liver transplantation for hepatocellular carcinoma in patients with normal, high and very high preoperative alpha-fetoprotein levels. World J Hepatol. 2018; 10:308-18. https://doi.org/10.4254/wjh.v10.i2.308. [PubMed]

6. Bozorgzadeh A, Orloff M, Abt P, Tsoulfas G, Younan D, Kashyap R, Jain A, Mantry P, Maliakkal B, Khorana A, Schwartz S. Survival outcomes in liver transplantation for hepatocellular carcinoma, comparing impact of hepatitis C versus other etiology of cirrhosis. Liver Transpl. 2007; 13:807-13. https://doi.org/10.1002/lt.21054. [PubMed]

7. Yu YP, Liu P, Nelson J, Hamilton RL, Bhargava R, Michalopoulos G, Chen Q, Zhang J, Ma D, Pennathur A, Luketich J, Nalesnik M, Tseng G, Luo JH. Identification of recurrent fusion genes across multiple cancer types. Sci Rep. 2019; 9:1074. https://doi.org/10.1038/s41598-019-38550-6. [PubMed]

8. Luo JH, Liu S, Zuo ZH, Chen R, Tseng GC, Yu YP. Discovery and classification of fusion transcripts in prostate cancer and normal prostate tissue. Am J Pathol. 2015; 185:1834-45. https://doi.org/10.1016/j.ajpath.2015.03.008. [PubMed] 
9. Yu YP, Ding Y, Chen Z, Liu S, Michalopoulos A, Chen R, Gulzar ZG, Yang B, Cieply KM, Luvison A, Ren BG, Brooks JD, Jarrard D, et al. Novel fusion transcripts associate with progressive prostate cancer. Am J Pathol. 2014; 184:2840-49. https://doi.org/10.1016/j.ajpath.2014.06.025. [PubMed]

10. Chen ZH, Yu YP, Tao J, Liu S, Tseng G, Nalesnik M, Hamilton R, Bhargava R, Nelson JB, Pennathur A, Monga SP, Luketich JD, Michalopoulos GK, Luo JH. MAN2A1-FER Fusion Gene Is Expressed by Human Liver and Other Tumor Types and Has Oncogenic Activity in Mice. Gastroenterology. 2017; 153:1120-1132.e15. https://doi.org/10.1053/j.gastro.2016.12.036. [PubMed]

11. Hanahan D, Weinberg RA. Hallmarks of cancer: the next generation. Cell. 2011; 144:646-74. https://doi.org/10.1016/j.cell.2011.02.013. [PubMed]

12. Hanahan D, Weinberg RA. The hallmarks of cancer. Cell. 2000; 100:57-70. https://doi.org/10.1016/S0092-8674(00)81683-9. [PubMed]

13. Klijn C, Durinck S, Stawiski EW, Haverty PM, Jiang Z, Liu H, Degenhardt J, Mayba O, Gnad F, Liu J, Pau G, Reeder J, Cao Y, et al. A comprehensive transcriptional portrait of human cancer cell lines. Nat Biotechnol. 2015; 33:306-12. https://doi.org/10.1038/nbt.3080. [PubMed]

14. Yoshihara K, Wang Q, Torres-Garcia W, Zheng S, Vegesna R, Kim H, Verhaak RG. The landscape and therapeutic relevance of cancer-associated transcript fusions. Oncogene. 2015; 34:4845-54. https://doi.org/10.1038/onc.2014.406. [PubMed]

15. Yang J, Chen $Y$, Lu J, Wang X, Wang L, Liang $J$, Sun ZS. Identification and characterization of novel fusion genes in prostate cancer by targeted RNA capture and next-generation sequencing. Acta Biochim Biophys Sin (Shanghai). 2018; 50:1166-72. https://doi.org/10.1093/abbs/gmy112. [PubMed]

16. Li W, Cagle PT, Botero RC, Liang JJ, Zhang Z, Tan D. Significance of overexpression of alpha methylacyl-coenzyme A racemase in hepatocellular carcinoma. J Exp Clin Cancer Res. 2008; 27:2. https://doi.org/10.1186/1756-9966-27-2. [PubMed]

17. Huang W, Zhao J, Li L, Huang Y, Yang X, Wang J, Zhang T. a-Methylacyl coenzyme A racemase is highly expressed in the intestinal-type adenocarcinoma and high-grade dysplasia lesions of the stomach. Histol Histopathol. 2008; 23:1315-20. https://doi.org/10.14670/HH-23.1315. [PubMed]

18. Shilo K, Dracheva T, Mani H, Fukuoka J, Sesterhenn IA, Chu WS, Shih JH, Jen J, Travis WD, Franks TJ. Alpha-methylacyl CoA racemase in pulmonary adenocarcinoma, squamous cell carcinoma, and neuroendocrine tumors: expression and survival analysis. Arch Pathol Lab Med. 2007; 131:1555-60. [PubMed]

19. Lee WA. Alpha-methylacyl-CoA-racemase expression in adenocarcinoma, dysplasia and non-neoplastic epithelium of the stomach. Oncology. 2006; 71:246-50. https://doi.org/10.1159/000106428. [PubMed]

20. Zha S, Ferdinandusse S, Denis S, Wanders RJ, Ewing CM, Luo J, De Marzo AM, Isaacs WB. Alpha-methylacyl-CoA racemase as an androgen-independent growth modifier in prostate cancer. Cancer Res. 2003; 63:7365-76. [PubMed]

21. Zhou M, Chinnaiyan AM, Kleer CG, Lucas PC, Rubin MA. Alpha-Methylacyl-CoA racemase: a novel tumor marker over-expressed in several human cancers and their precursor lesions. Am J Surg Pathol. 2002; 26:926-31. https://doi.org/10.1097/00000478-200207000-00012. [PubMed]

22. Rubin MA, Zhou M, Dhanasekaran SM, Varambally S, Barrette TR, Sanda MG, Pienta KJ, Ghosh D, Chinnaiyan AM. alpha-Methylacyl coenzyme A racemase as a tissue biomarker for prostate cancer. JAMA. 2002; 287:1662-70. https://doi.org/10.1001/jama.287.13.1662. [PubMed]

23. Luo J, Zha S, Gage WR, Dunn TA, Hicks JL, Bennett CJ, Ewing CM, Platz EA, Ferdinandusse S, Wanders RJ, Trent JM, Isaacs WB, De Marzo AM. Alpha-methylacyl-CoA racemase: a new molecular marker for prostate cancer. Cancer Res. 2002; 62:2220-26. [PubMed]

24. Kuefer R, Varambally S, Zhou M, Lucas PC, Loeffler M, Wolter H, Mattfeldt T, Hautmann RE, Gschwend JE, Barrette TR, Dunn RL, Chinnaiyan AM, Rubin MA. alpha-Methylacyl-CoA racemase: expression levels of this novel cancer biomarker depend on tumor differentiation. Am J Pathol. 2002; 161:841-48. https://doi.org/10.1016/S0002-9440(10)64244-7. [PubMed]

25. Kastelein F, Biermann K, Steyerberg EW, Verheij J, Kalisvaart M, Looijenga LH, Stoop HA, Walter L, Kuipers EJ, Spaander MC, Bruno MJ, and ProBar study group. Value of $\alpha$-methylacyl-CoA racemase immunochemistry for predicting neoplastic progression in Barrett's oesophagus. Histopathology. 2013; 63:630-39. https://doi.org/10.1111/his.12216. [PubMed]

26. Festuccia C, Gravina GL, Mancini A, Muzi P, Cesare ED, Kirk R, Smith M, Hughes S, Gibson R, Lian LY, Ricevuto E, Carnell AJ. Trifluoroibuprofen inhibits $\alpha$-methylacyl coenzyme A racemase (AMACR/P504S), reduces cancer cell proliferation and inhibits in vivo tumor growth in aggressive prostate cancer models. Anticancer Agents Med Chem. 2014; 14:1031-41. https://doi.org/10.2174/1871520614666140327152607. [PubMed]

27. Mäkelä TP, Parvin JD, Kim J, Huber LJ, Sharp PA, Weinberg RA. A kinase-deficient transcription factor TFIIH is functional in basal and activated transcription. Proc Natl Acad Sci USA. 1995; 92:5174-78. https://doi.org/10.1073/pnas.92.11.5174. [PubMed]

28. Fisher RP, Morgan DO. A novel cyclin associates with MO15/CDK7 to form the CDKactivating kinase. Cell. 1994; 78:713-24. https://doi.org/10.1016/0092-8674(94)90535-5. [PubMed]

29. Andersen G, Busso D, Poterszman A, Hwang JR, Wurtz JM, Ripp R, Thierry JC, Egly JM, Moras D. The structure of cyclin $\mathrm{H}$ : common mode of kinase activation 
and specific features. EMBO J. 1997; 16:958-67. https://doi.org/10.1093/emboj/16.5.958. [PubMed]

30. Paschen W, Blackstone CD, Huganir RL, Ross CA. Human GluR6 kainate receptor (GRIK2): molecular cloning, expression, polymorphism, and chromosomal assignment. Genomics. 1994; 20:435-40. https://doi.org/10.1006/geno.1994.1198. [PubMed]

31. Wu CS, Lu YJ, Li HP, Hsueh C, Lu CY, Leu YW, Liu HP, Lin KH, Hui-Ming Huang T, Chang YS. Glutamate receptor, ionotropic, kainate 2 silencing by DNA hypermethylation possesses tumor suppressor function in gastric cancer. Int $\mathrm{J}$ Cancer. 2010; 126:2542-52. https://doi.org/10.1002/ijc.24958. [PubMed]

32. Towns WL, Begley TJ. Transfer RNA methytransferases and their corresponding modifications in budding yeast and humans: activities, predications, and potential roles in human health. DNA Cell Biol. 2012; 31:434-54. https://doi.org/10.1089/dna.2011.1437. [PubMed]

33. Bourgeois G, Marcoux J, Saliou JM, Cianférani S, Graille M. Activation mode of the eukaryotic m2G10 tRNA methyltransferase Trm11 by its partner protein Trm112. Nucleic Acids Res. 2017; 45:1971-82. https://doi.org/10.1093/nar/gkw1271. [PubMed]

34. Chen ZH, Yu YP, Zuo ZH, Nelson JB, Michalopoulos GK, Monga S, Liu S, Tseng G, Luo JH. Targeting genomic rearrangements in tumor cells through Cas9-mediated insertion of a suicide gene. Nat Biotechnol. 2017; 35:54350. https://doi.org/10.1038/nbt.3843. [PubMed]

35. He DM, Ren BG, Liu S, Tan LZ, Cieply K, Tseng G, Yu YP, Luo JH. Oncogenic activity of amplified miniature chromosome maintenance 8 in human malignancies. Oncogene. 2017; 36:3629-39. https://doi.org/10.1038/onc.2017.123. [PubMed]

36. Zuo ZH, Yu YP, Ding Y, Liu S, Martin A, Tseng G, Luo JH. Oncogenic Activity of miRNA 650 in Prostate Cancer Is Mediated by Suppression of CSR1 Expression. Am J Pathol. 2015; 185:1991-9. https://doi.org/10.1016/j.ajpath.2015.03.015. [PubMed]

37. Yu YP, Michalopoulos A, Ding Y, Tseng G, Luo JH. High fidelity copy number analysis of formalinfixed and paraffin-embedded tissues using Affymetrix Cytoscan HD chip. PLoS One. 2014; 9:e92820. https://doi.org/10.1371/journal.pone.0092820. [PubMed]

38. Nalesnik MA, Tseng G, Ding Y, Xiang GS, Zheng ZL, Yu Y, Marsh JW, Michalopoulos GK, Luo JH. Gene deletions and amplifications in human hepatocellular carcinomas: correlation with hepatocyte growth regulation. Am J Pathol. 2012; 180:1495-508. https://doi.org/10.1016/j.ajpath.2011.12.021. [PubMed]

39. Han YC, Yu YP, Nelson J, Wu C, Wang $\mathrm{H}$, Michalopoulos GK, Luo JH. Interaction of integrinlinked kinase and miniature chromosome maintenance 7-mediating integrin \{alpha\}7 induced cell growth suppression. Cancer Res. 2010; 70:4375-84. https://doi.org/10.1158/0008-5472.CAN-09-4403. [PubMed]
40. Yu YP, Yu G, Tseng G, Cieply K, Nelson J, Defrances M, Zarnegar R, Michalopoulos G, Luo JH. Glutathione peroxidase 3, deleted or methylated in prostate cancer, suppresses prostate cancer growth and metastasis. Cancer Res. 2007; 67:8043-50. https://doi.org/10.1158/0008-5472.CAN-07-0648. [PubMed]

41. Ren B, Yu YP, Tseng GC, Wu C, Chen K, Rao UN, Nelson J, Michalopoulos GK, Luo JH. Analysis of integrin alpha7 mutations in prostate cancer, liver cancer, glioblastoma multiforme, and leiomyosarcoma. J Natl Cancer Inst. 2007; 99:868-80. https://doi.org/10.1093/jnci/djk199. [PubMed]

42. Yu G, Tseng GC, Yu YP, Gavel T, Nelson J, Wells A, Michalopoulos G, Kokkinakis D, Luo JH. CSR1 suppresses tumor growth and metastasis of prostate cancer. Am J Pathol. 2006; 168:597-607. https://doi.org/10.2353/ajpath.2006.050620. [PubMed]

43. Luo JH, Ren B, Keryanov S, Tseng GC, Rao UN, Monga SP, Strom S, Demetris AJ, Nalesnik M, Yu YP, Ranganathan S, Michalopoulos GK. Transcriptomic and genomic analysis of human hepatocellular carcinomas and hepatoblastomas. Hepatology. 2006; 44:1012-24. https://doi.org/10.1002/hep.21328. [PubMed]

44. Yu YP, Landsittel D, Jing L, Nelson J, Ren B, Liu L, McDonald C, Thomas R, Dhir R, Finkelstein $\mathrm{S}$, Michalopoulos G, Becich M, Luo JH. Gene expression alterations in prostate cancer predicting tumor aggression and preceding development of malignancy. J Clin Oncol. 2004; 22:2790-99. https://doi.org/10.1200/JCO.2004.05.158. [PubMed]

45. Ren B, Yu YP, Jing L, Liu L, Michalopoulos GK, Luo $\mathrm{JH}$, Rao UN. Gene expression analysis of human soft tissue leiomyosarcomas. Hum Pathol. 2003; 34:549-58. https://doi.org/10.1016/S0046-8177(03)00014-5. [PubMed]

46. Luo JH, Yu YP, Cieply K, Lin F, Deflavia P, Dhir R, Finkelstein S, Michalopoulos G, Becich M. Gene expression analysis of prostate cancers. Mol Carcinog. 2002; 33:25-35. https://doi.org/10.1002/mc.10018. [PubMed]

47. Yu YP, Lin F, Dhir R, Krill D, Becich MJ, Luo JH. Linear amplification of gene-specific cDNA ends to isolate fulllength of a cDNA. Anal Biochem. 2001; 292:297-301. https://doi.org/10.1006/abio.2001.5066. [PubMed]

48. Yu YP, Lin F, Bisceglia M, Krill D, Dhir R, Becich M, Luo JH. Identification of a novel gene with increasing rate of suppression in high grade prostate cancers. Am J Pathol. 2001; 158:19-24. https://doi.org/10.1016/S0002-9440(10)63939-9. [PubMed]

49. Lin F, Yu YP, Woods J, Cieply K, Gooding B, Finkelstein P, Dhir R, Krill D, Becich MJ, Michalopoulos G, Finkelstein $\mathrm{S}$, Luo JH. Myopodin, a synaptopodin homologue, is frequently deleted in invasive prostate cancers. Am J Pathol. 2001; 159:1603-12. https://doi.org/10.1016/S00029440(10)63006-4. [PubMed] 